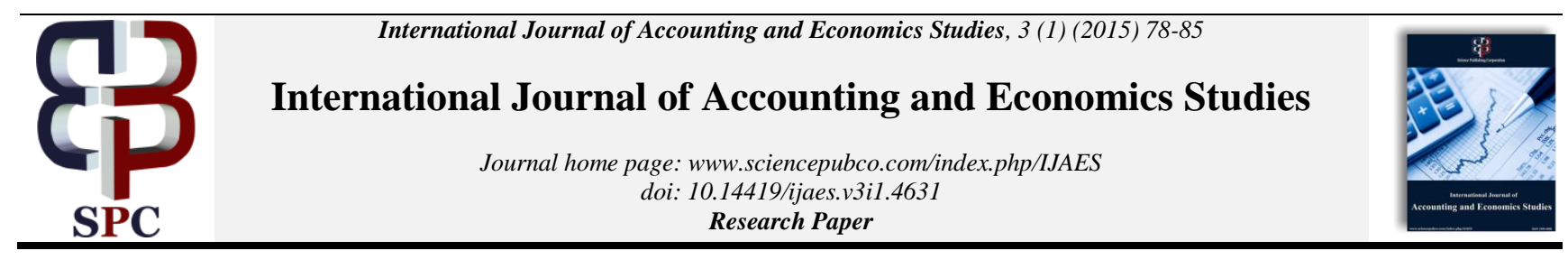

\title{
The determinants of issuers' long term credit ratings : American S\&P500 index
}

\author{
Afef Feki *, Walid Khoufi \\ Department of Accounting and Finance, Institute of Business Studies of Sfax (IHECS), Tunisia \\ *Corresponding author E-mail: feki.afef@gmail.com
}

\begin{abstract}
In this paper, we examine the impact that various financial and business profile variables have on credit ratings issued for the S\&P500 firms by Moody's. Our ordered probit model indicates that firms' financial policy, size, liquidity, interest and debt coverage have the most pronounced effect on credit ratings. Our results show that different coefficients are associated to the increments of interest and debt coverage ratios. Business profile variables are not significant. Liquidity variable is also a significant determinant of the issuer long-term credit rating and not just the short term one.
\end{abstract}

Keywords: Credit Ratings; Determinants; Interest and Debt Coverage; Ordered Probit Model.

\section{Introduction}

The credit rating is an independent assessment of a company's ability to pay its debts in a timely manner. It can be attributed to a particular debt issue or to a general ability of a company to pay its debts. Rating agencies use quantitative and qualitative information available to the public or from other private sources, to assess ratings.

In practice, the credit rating is of great importance since it affects the cost of debt, the capital structure and even the negotiating capacity of a firm. From the investors' perspective, the rating is an independent source of credit analysis used for regulatory reasons and to reduce agency costs. For example, in the United States in 1999, there were more than 1000 references to ratings in regulations of securities markets and nearly 400 for banks. Some companies restrict investment in bonds lower than the investment grade.

In 2008, the SEC issued a report on the role of rating agencies in the financial crisis. Later, the US Senate report published in 2011, criticized the two leaders of ratings, Moody's and Standard \& Poor's, for using inadequate ratings models'.

However, if the question of rating methodologies is finally imposed in thinking about the role of the credit rating agencies, no supervisor or international organization is responsible of that validation, which remains a prerogative of the agencies (Senate report of information on the rating agencies, 2012).

The effect of this irresponsibility is intensifying on capital and financial markets, from the last subprime financial crisis. Many questions arise on the agencies' practices and on ratings effects on debt access and costs. These facts led us to wonder about rating methodologies, and especially factors used by agencies to assess their ratings.

Previous studies (Hwang et al. 2010, Cheng et al. 2009, Lee 2007, Gray et al. 2006, Kumar \& Bhattacharya 2006, and Poon 2003) have always used the same financial ratios in determining the issuer long-term credit ratings.

In this paper and in order to achieve real results, we have chosen to use the ratios used in Moody's rating methodology, particularly. Ratios reflecting interest and debt coverage, profitability, liquidity, firm's size, financial policy and variables reflecting business profile. We examine the relationship between Moody's credit ratings and a set of financial ratios and business profile variables. We follow the existing literature (Blume et al. 1998, Gray et al. 2006) in using an ordered probit model to map our explanatory variables into credit ratings assigned by Moody to the American firms of the S\&P 500 index between 2008 and 2010. We find that financial policy, size, liquidity, interest coverage and debt coverage have the most pronounced effect on credit ratings. Different coefficients are associated to the increments of interest and debt coverage ratios. Business profile variables are not significant. Liquidity variable is also a significant determinant of the issuer long-term credit rating and not just the short term one. The particularity of this period driven by a financial turmoil, can explain why some variables are more significant than others. For example, the nonsignificance of business profile variables is due to the fact that financial distress makes product and geographic diversification difficult and inappropriate for firms. Although this model can also be a good forecaster for periods with different characteristics, results can be different.

This paper extends the analysis of Gray et al. (2006) in a number of directions. First, we apply the ordered probit model to American firms for recent data. Second, we use ratios published in Moody's rating methodology, instead of financial ratios used in the literature. Third, we test for the first time the existence of different weights associated with different increments of the debt coverage ratios.

The remainder of this paper is organized as follows. In section 2, we present the relevant literature in relation with this paper.

Section 3 describes the sample selection and data: description of financial ratios used and necessary transformations made for these ratios. Section 4 develops the ordered probit model used to map 
financial ratios and business profile variables to the issuer longterm credit rating. The results are discussed in section 5 and the conclusion in section 6 .

\section{Relevant literature}

The finance literature generally uses publicly available information to predict credit ratings and corporate bankruptcy. Even if these two concepts are different, there is a strong relationship between them. Bonds with lower ratings are more likely to defaults than bonds with higher ratings. The prediction of credit ratings is difficult for several reasons. The use of a scale with nine major grades, by Moody's and Standard and Poor's, makes that a simple discriminant analysis is inappropriate and a more complex economic technique will be required. In addition, the fact that credit ratings are based on quantitative and qualitative data available to the public and from other private sources makes credit rating assessment more difficult.

Previous research on credit rating prediction divides logically into three branches.

First, we find studies concerned with the techniques used to credit rating prediction. Several techniques were used including multiple regression analysis (Horrigan 1966, Pogue \& Soldofsky 1969, West 1970), multiple discriminant analysis (Pinches \& Mingo 1973, Altman \& Katz 1976), ordered linear probit model (Kaplan \& Urwitz 1979, Ederington 1985, Poon 2003, Cheng et al. 2009 Hwang et al. 2010), ordered and unordered linear logit models (Ederington 1985), Bayesian networks (Wijayatunga et al. 2006) and support vector machines and neural networks (Huang et al. 2004).

Second, Blume et al. (1998), by examining the determinants of bonds ratings,' focus on the changing standards used in assigning ratings. They showed that ratings degradations' no longer reflect deterioration in their quality, but the use of stringent rating standards. They suggest that if it were not for the use of more stringent rating standards, the level of bond ratings might have actually been higher today than in the past. Another explanation of their results is that the meanings of the firm variables used to have changed over time. For example, it could be that an interest coverage of 5 ten years ago indicated a higher creditworthiness than the same value does today.

Third, we find studies concerned with assigning ratings to particular bond issues (Pogue \& Soldofsky 1969, West 1970, Pinches \& Mingo 1973, Blume et al. 1998). Pinches \& Mingo (1973) use factor analysis to arrive at a set of six factors considered determinants of bond issues ratings: subordination, years of consecutive dividends, issue size and three financial ratios. These factors differ significantly from those considered determinants of issuer ratings defined as firms' size, financial leverage, coverage, cash flow, profitability, liquidity, market-driven variables and industry variables (Hwang et al. 2010).

The Only study whose aim was to provide the determinants of credit ratings was that of Gray et al. (2006) using Australian data, but it does not use the variables published by Moody's rating methodology.

\section{Sample selection and data}

Our initial sample consists of American companies that belong to the S\&P500 index. Historical long-term issuer credit ratings are obtained through the Moody's Ratings website. Ratios and financial information for the period 2008 to 2010 are collected from Thomson Reuters Datastream of the Worldscope Base. Taking into account that financial reports are available to the public three to four months after the end of a year and that rating agencies use the financial information disclosed in the annual reports in their rating process, we took for each company the rating disclosed four months after the financial-year end (Hwang et al. 2010, Cheng et al. 2009 and Moody's 2004). Financial firms are excluded from the sample due to significant differences in accounting standards and rating methodologies. Also, companies that are not rated by Moody and those that are withdrawn rating by Moody are excluded. In addition, non-American companies are excluded as we have not included the sovereign rating, among the determinants of long term issuer credit rating. Finally, companies rated Caa1, Caa2 and $\mathrm{Ca}$ are also removed from the sample because of their minority compared to the total sample. The total number of firms that meet the above criteria is 315 . Figure 1 provides the distribution of our sample by ratings. Most observations are clustered in the A and Baa categories (more than 60\%). While the Aaa, Aa and B categories cover near $40 \%$ of our sample, the Caa and Ca categories form a minority. The distribution of our sample by industry is presented in Figure 2. This indicates that the majority of the firms are clustered in the industrial and the consumer cyclical. The healthcare, consumer non-cyclical, energy, technology and utilities industries present similar percentages.

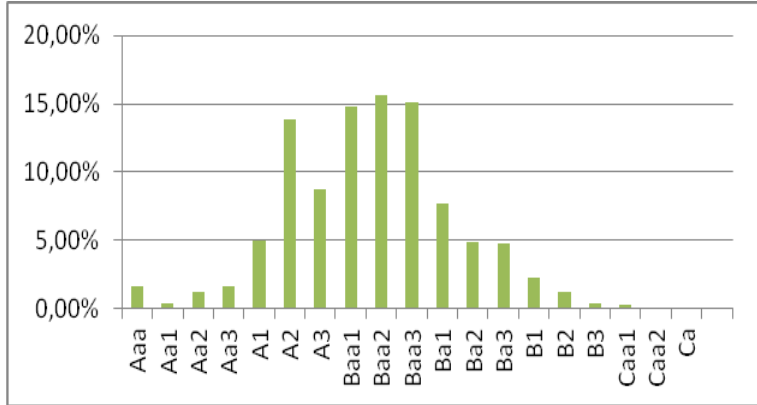

Fig. 1: Distribution of Sample Observations by Ratings

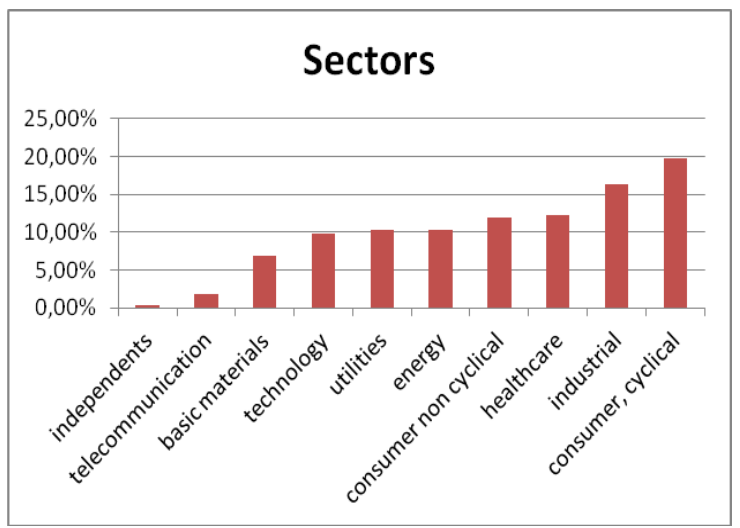

Fig. 2: Distribution of Sample Observations by Industry

\subsection{Financial ratios}

Consistent with the rating methodology published by Moody's (2010), except of some variables, we model the firm's credit ratings as a function of its financial characteristics; given by size, profitability, liquidity, debt coverage, interest coverage and financial policy; and of its profile given by-product and geographic diversification. First, to measure profitability, we used return on assets instead of return on average assets, due to data availability, and we added return on equity as a second measure. Second, to measure debt coverage, we haven't included the ratio of retained cash flow to net debt, due to the unavailability of data for most companies in the sample. Finally, we have included the liquidity in this research; although it has not been involved by previous studies (except Lee 2007) either by Moody's rating methodology. Product and geographic diversification, measured by the number of main areas of activity and the average number of regions for which the company distributes its products during the past three years, tend to lead to higher credit ratings. Firms with higher interest coverage ratios, measured by the EBITDA relative to inter. ests, are likely to have higher credit rating. Cash flow or debt coverage ratios, such as free cash flow or funds from operations relative to total debts, lead also to higher credit ratings. Another key factor is the firm's financial policy, measured by total debts relative to common equity or total debts relative to EBITDA. Higher 
leverage is usually associated with lower credit ratings. High Profitability, measured by higher returns on equity and returns on assets, tend to be associated with higher credit ratings. Another key factor is liquidity, measured by quick ratio and current ratio. Higher liquidity is symptomatic of higher ability of the firm to invest in future projects and tend to lead to higher credit ratings. Finally, firm's size, measured by the total revenues and the EBITDA, tend to have a positive impact on other key factors of ratings. Large firms tend to receive higher credit ratings.

According to S\&P and Moody's rating methodologies, we adopted a process called "rating through the cycle" to measure financial ratios. This process is considering a long-term perspective by using three-year averages of financial ratios rather than just the final recent year. We follow this process using data from 2006 to 2010 .

\subsection{Transformation of financial ratios}

In this paper, we model credit ratings as depending on a linear function of the independent variables. We find that some of these explanatory variables are highly skewed. In particular, we find a number of extreme outliers in the interest and debt coverage ratios. This problem may return to negative denominators, negative nominators and denominators and denominators tending to zero. So, the linear relationship assumed between these variables and the credit rating may be violated. As a result, some corrections to the interest and debt coverage ratios seem necessary before making the empirical tests. According to Blume et al. (1998), Amato \& Furfine (2004), two corrections are made to the variable interest coverage. First, each negative observation, before calculating the average over three years, is set to zero. In addition, each average greater than 100 is set to 100 , assuming that any increase beyond this value doesn't give any additional information. They find that the coefficient on the increment of the interest coverage ratio from 0 to $5, \mathrm{~K} 1$, is positive and large and differs significantly from zero. The coefficient on the increment of the interest coverage ratio from 5 to $10, \mathrm{~K} 2$, and from 10 to $20, \mathrm{~K} 3$, are positive and small but differ significantly from zero. The coefficient on the increment above $20, \mathrm{~K} 4$, is not significantly different from zero.

Debt coverage variables are also corrected to avoid the limitations of extreme observations. Increments beyond one indicate that firm's cash flow is more than sufficient to cover its debts.

Gray et al. (2006) replace each average less than negative one is set to $(-1)$ and each average greater than 5 is set to 5 . The observation of debt coverage variables supports our previsions that increments of these ratios don't have the similar effects on credit ratings. We make assumptions that different coefficients are associated with different increments of the debt coverage ratios: L1 for the increment from negative one to zero, $\mathrm{L} 2$, for the increment from zero to 1, L3, for the increment from one to three and L4 for the increment from three to five. Finally, negative leverage ratios are set to zero. For the other variables, a $90 \%$ winsorization has been applied to adjust the effects of extreme outliers. The bottoms $5 \%$ of the observations are set to the 5 th percentile while the uppers $5 \%$ of the observations are set equal to the 95th percentile.

Descriptive statistics for variables by rating category are presented in table 1.

Table 1: Descriptive Statistics of Transformed and Business Profile Variables

\begin{tabular}{|c|c|c|c|c|c|}
\hline Variables & Mean & Median & Standard Deviation & Min & Max \\
\hline \multicolumn{6}{|l|}{ Bus-Seg-Aver } \\
\hline Аaа-Aa1-Aa2-Aa3 & 3,77 & 3,5 & 1,8465 & 1 & 9 \\
\hline $\mathrm{A} 1-\mathrm{A} 2-\mathrm{A} 3$ & 3,42 & 3 & 1,8928 & 1 & 8 \\
\hline Ваa1-Ваa2-Ваa3 & 3,31 & 3 & 1,7322 & 1 & 8 \\
\hline $\mathrm{Ba} 1-\mathrm{Ba} 2-\mathrm{Ba} 3$ & 3,07 & 3 & 1,5844 & 1 & 6 \\
\hline B1-B2-B3 & 2,92 & 3 & 1,4771 & 1 & 7 \\
\hline \multicolumn{6}{|l|}{ Geo-Seg-Aver } \\
\hline Aaa-Aa1-Aa2-Aa3 & 3,2 & 3 & 2,4550 & 1 & 10 \\
\hline A1-A2-A3 & 3,65 & 3 & 2,3298 & 1 & 10 \\
\hline Ваa1-Baа2-Baа3 & 3 & 3 & 1,9692 & 1 & 10 \\
\hline Ba1-Ba2-Ba3 & 3,3 & 3 & 1,8675 & 1 & 8 \\
\hline B1-B2-B3 & 4,15 & 3,5 & 2,8424 & 1 & 10 \\
\hline \multicolumn{6}{|l|}{ Rev-Aver } \\
\hline Aaa-Aa1-Aa2-Aa3 & 23780,55 & 18350,42 & 19661,02 & 1954,697 & 70528 \\
\hline A1-A2-A3 & 17091,92 & 8767,6583 & 19272,32 & 0 & 73301,23 \\
\hline Ваa1-Ваa2-Ваa3 & 15845,6 & 8605 & 19035,78 & 0 & 78307,34 \\
\hline $\mathrm{Ba} 1-\mathrm{Ba} 2-\mathrm{Ba} 3$ & 13469,78 & 7170,833 & 17666,32 & 994,073 & 75886,34 \\
\hline B1-B2-B3 & 9539,312 & 6680,55 & 7500,073 & 1270,537 & 29392 \\
\hline \multicolumn{6}{|l|}{ EBITDA-Aver } \\
\hline Aaа-Aa1-Aa2-Aa3 & 2803,462 & 2586 & 2108,011 & $-1117,667$ & 11763 \\
\hline A1-A2-A3 & 2638,438 & 1343,333 & 3018,66 & $-1429,888$ & 11502,2 \\
\hline Baa1-Baa2-Baa3 & 2527,368 & 1351,597 & 3011,155 & $-2494,667$ & 8419,333 \\
\hline Ba1-Ba2-Ba3 & 2012,263 & 1121 & 1856,197 & $-443,666$ & 8569,667 \\
\hline B1-B2-B3 & 1620,307 & 1110 & 1583,963 & $-692,666$ & 4975,667 \\
\hline \multicolumn{6}{|l|}{ FFO/TD-Avera } \\
\hline Aaa-Aa1-Aa2-Aa3 & 0,5592 & 0,4099 & 0,5638 & -1 & 9,3439 \\
\hline A1-A2-A3 & 1,0924 & 0,5352 & 1,3019 & 0,0541 & 5 \\
\hline Baa1-Baa2-Baa3 & 1,025 & 0,5005 & 1,4957 & 0,0386 & 5 \\
\hline Ba1-Ba2-Ba3 & 0,9842 & 0,4607 & 1,2161 & $-0,0244$ & 5 \\
\hline B1-B2-B3 & 0,5930 & 0,2714 & 1,0700 & 0,059 & 2,2037 \\
\hline \multicolumn{6}{|l|}{ FCF/TD-Aver } \\
\hline Aaa-Aa1-Aa2-Aa3 & 0,1997 & 0,1795 & 0,3853 & -1 & 1,0979 \\
\hline A1-A2-A3 & 0,6733 & 0,3053 & 1,2058 & $-0,2464$ & 5 \\
\hline Ваa1-Baа2-Baа3 & 0,5363 & 0,2359 & 1,1575 & $-1,7472$ & 5 \\
\hline $\mathrm{Ba} 1-\mathrm{Ba} 2-\mathrm{Ba} 3$ & 0,4706 & 0,2420 & 0,9371 & $-0,7046$ & 5 \\
\hline B1-B2-B3 & 0,3753 & 0,1238 & 0,7701 & $-0,2730$ & 2,8095 \\
\hline \multicolumn{6}{|l|}{ EBITDA/INT-Aver } \\
\hline Aaa-Aa1-Aa2-Aa3 & 13,9272 & 9,2019 & 12,7772 & 0 & 51,112 \\
\hline A1-A2-A3 & 20,1957 & 12,3575 & 21,5501 & 0 & 100 \\
\hline Baa1-Baa2-Baa3 & 16,8923 & 9,3944 & 21,0186 & 0,0986 & 100 \\
\hline Ba1-Ba2-Ba3 & 20,6658 & 10,5041 & 24,3653 & 0,0018 & 100 \\
\hline B1-B2-B3 & 20,6197 & 7,4664 & 32,7939 & $-0,3863$ & 100 \\
\hline \multicolumn{6}{|l|}{ ROA-Aver } \\
\hline Aaa-Aa1-Aa2-Aa3 & 8,3893 & 7,9515 & 6,6058 & $-6,7570$ & 31,8246 \\
\hline
\end{tabular}




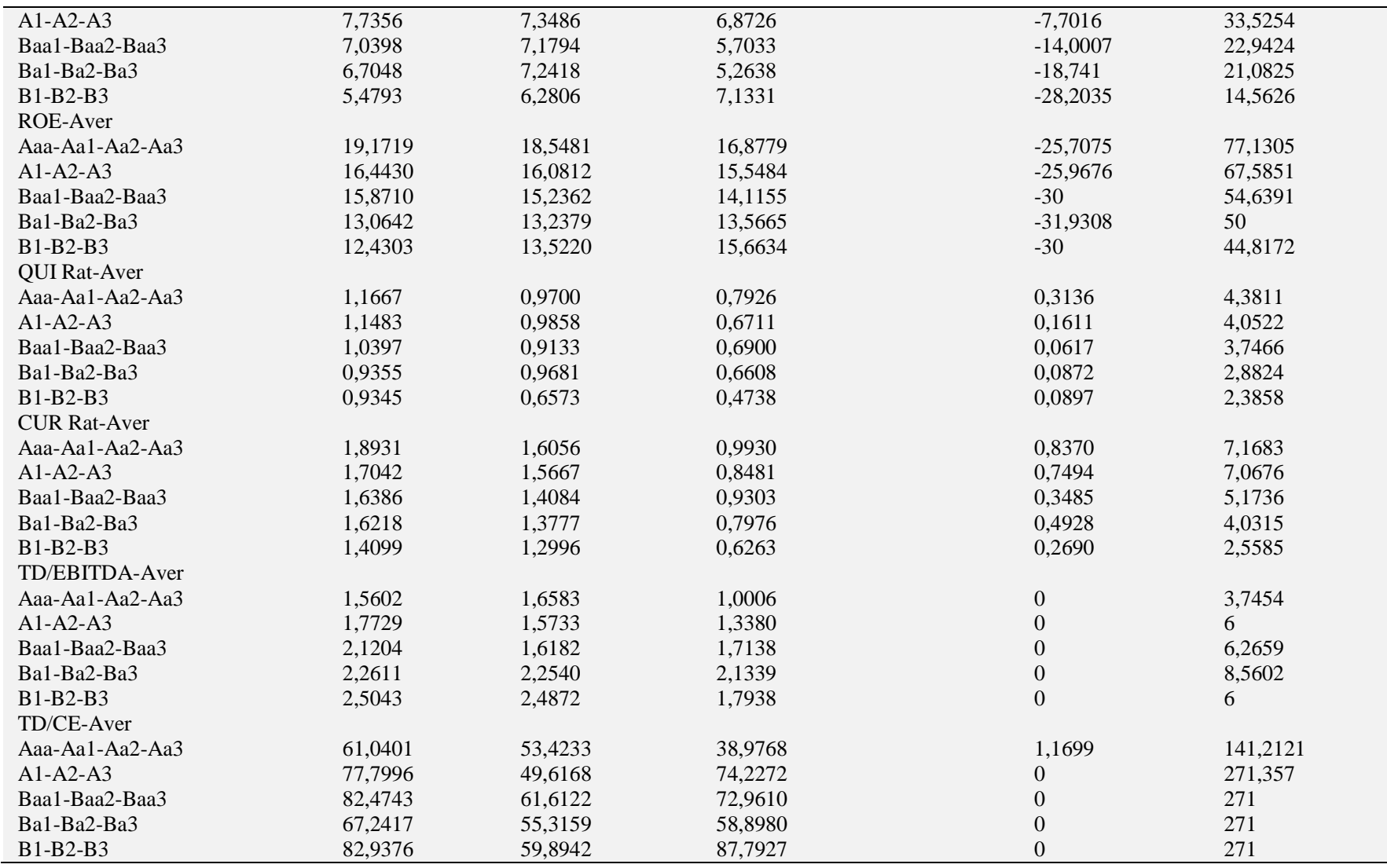

The average business segment, profitability, liquidity and size are greater for the firms with higher credit ratings. As expected, the $\mathrm{Ba} 1-\mathrm{Ba} 2-\mathrm{Ba} 3$ rated firms have the highest interest coverage ratios and the Aaa-Aa1-Aa2-Aa3 have the lowest ones. Similarly, the A1-A2-A3 firms have the highest debt coverage even better than that of firms rated Aaa-Aa1-Aa2-Aa3.

This confirms that the evolution of these ratios is not monotonic and justifies the changes we made for to better reflect their effects on the assessment of credit rating.

On the other hand, the B1-B2-B3 rated firms have the highest average geographic segments but the A1-A2-A3 rated firms have higher values than the Aaa-Aa1-Aa2-Aa3 rated ones.

This indicates that rating agencies don't place more weight on the number of geographic segments.

For financial policy, the debt to EBITDA ratio is higher for firms with lower ratings. The B1-B2-B3 rated firms have the highest debt to common equity ratio but the Aaa-Aa1-Aa2-Aa3 rated ones have the lowest values.

\section{The model}

In this paper, we seek to relate financial and industry variables to credit ratings. The approach we adopt is the ordered probit model as implemented in a credit rating setting initially by Blume et al. (1998) and then by Gray et al. (2006). This method is designed for studies in which the dependent variable takes a finite number of values that possess a natural ordering. We develop five ordered rating classes: Aaa/Aa1/Aa2/Aa3, A1/A2/A3, Baa1/Baa2/Baa3, $\mathrm{Ba} 1 / \mathrm{Ba} 2 / \mathrm{Ba} 3$ and $\mathrm{B} 1 / \mathrm{B} 2 / \mathrm{B} 3$.

The dependent variable, the credit rating of company $\mathrm{i}$ in a year $\mathrm{t}$, Yit, takes 1 if the company is rated B1, B2 or B3, 2 if the company is rated $\mathrm{Ba} 1, \mathrm{Ba} 2$ or $\mathrm{Ba} 3,3$ if the company is rated $\mathrm{Baa} 1, \mathrm{Baa} 2$ or $\mathrm{Baa} 3,4$ if the company is rated $\mathrm{A} 1, \mathrm{~A} 2$, or $\mathrm{A} 3$ and 5 if it is rated Aaa, Aa1, Aa2 or Aa3.
$\mathrm{Y}_{\mathrm{it}}=\left\{\begin{array}{l}1 \text { if the company is rated } \mathrm{B} 1, \mathrm{~B} 2 \text { or } \mathrm{B} 3 \\ 2 \text { if the company is rated } \mathrm{Ba} 1, \mathrm{Ba} 2 \text { or } \mathrm{Ba} 3 \\ 3 \text { if the company is rated Baa1, Baa2 or Baa3 } \\ 4 \text { if the company is rated } \mathrm{A} 1, \mathrm{~A} 2 \text { or } \mathrm{A} 3 \\ 5 \text { if the company is rated Aaa, Aa1, Aa2 or Aa3 }\end{array}\right.$

To relate credit ratings to our explanatory variables, we define our model as:

$\mathrm{Y}^{*}{ }_{\mathrm{it}}=\beta \mathrm{X}^{\prime}{ }_{\mathrm{it}}+\boldsymbol{\varepsilon}_{\text {it }}$

Where:

Xit is a vector of explanatory variables reflecting the business profile, measured by 'Bus-Seg-aver' and 'Geo-Seg-aver'; the firm's size, measured by 'Rev-aver' and 'EBITDA-aver'; the firm's profitability, measured by 'ROA-aver' and 'ROE-aver'; the firm's liquidity, measured by 'QUI Rat-aver' and 'CUR Rat-aver'; the firm's debt coverage, measured by 'FFO/TD-aver' and 'FCF/TD-aver'; the firm's interest coverage, measured by 'EBITDA-INT-aver'; and finally the firm's financial policy, measured by 'TD/CE-aver' and 'TD/EBITDA-aver'.

$\beta$ is a vector of coefficients to be estimated and eit is a standard normal residual. The quantifiable factors are given by Xit and unobservable factors given by cit. Our ordered probit model relates the unobserved variable $\mathrm{Y} *$ it to the observed credit rating $\mathrm{Yit}$ as follows:

$$
\text { Yit }=\left\{\begin{array}{l}
1 \text { if } \mathrm{Y} * \text { it } \leq \alpha 1 \\
2 \text { if } \alpha 1<\mathrm{Y} * \text { it } \leq \alpha 2 \\
3 \text { if } \alpha 2<\mathrm{Y} * \text { it } \leq \alpha 3 \\
4 \text { if } \alpha 3<\mathrm{Y} * \text { it } \leq \alpha 4 \\
5 \text { if } \mathrm{Y} * \text { it }>\alpha 4
\end{array}\right.
$$


The probability of a set of explanatory variables being associated with a particular credit rating is given by:

$\operatorname{Pr}[$ Yit $=1]=\operatorname{Pr}\left[X^{\prime}\right.$ it $\beta+\varepsilon$ it $\left.\leq \alpha 1\right] \quad=\operatorname{Pr}\left[\varepsilon\right.$ it $\leq \alpha 1-X^{\prime}$ it $\left.\beta\right]$

$\operatorname{Pr}[$ Yit $=2]=\operatorname{Pr}\left[\alpha 1<X^{\prime}\right.$ it $\beta+\varepsilon$ it $\left.\leq \alpha 2\right]=\operatorname{Pr}\left[\alpha 1-X^{\prime}\right.$ it $\beta<\varepsilon$ it $\leq$

$\alpha 2-X^{\prime}$ it $\beta$ ]

$\operatorname{Pr}[$ Yit $=3]=\operatorname{Pr}\left[\alpha 2<X^{\prime}\right.$ it $\beta+\varepsilon$ it $\left.\leq \alpha 3\right]=\operatorname{Pr}\left[\alpha 2-X^{\prime}\right.$ it $\beta<\varepsilon$ it $\leq$

$\alpha 3-X^{\prime}$ it $\beta$ ]

$\operatorname{Pr}\left[\mathrm{Y}_{\mathrm{it}}=4\right]=\operatorname{Pr}\left[\alpha_{3}<X^{\prime}{ }_{i t} \beta+\varepsilon_{i t} \leq \alpha_{4}\right] \quad=\operatorname{Pr}\left[\alpha_{3}-X^{\prime}{ }_{i t} \beta<\varepsilon_{i t} \leq \alpha_{4}-\right.$

$\left.X^{\prime}{ }_{i t} \beta\right]$

$\operatorname{Pr}\left[\mathrm{Y}_{\mathrm{it}}=5\right]=\operatorname{Pr}\left[X^{\prime}{ }_{i t} \beta+\varepsilon_{i t}>\alpha_{4}\right] \quad=\operatorname{Pr}\left[\varepsilon_{i t}>\alpha_{4}-X^{\prime}{ }_{i t} \beta\right]$

Where $\varepsilon_{i t} \sim \mathrm{N}(0,1)$.

The parameters $\alpha 1, \alpha 2, \alpha 3$ and $\alpha 4$ are chosen to reflect the proportion of observations in the sample associated with each rating category. A large value of $\alpha 1$ increases the number of observations that are rated B1, B2 or B3. Thus these parameters $(\alpha 1, \alpha 2, \alpha 3$ and $\alpha 4)$ depend on the proportion of observations in the sample for each rating category. Large values of the linear combination of explanatory variables $\beta$ X'it, lead to better credit ratings (higher credit ratings, that take the value of 4 or 5 , lead to higher credit quality). We use the standard maximum likelihood techniques to estimate the coefficients $(\beta)$ and the values of $\alpha 1, \alpha 2, \alpha 3$ and $\alpha 4$.

The goodness of fit of the estimated probit model can be evaluated with reference to the percentage of sample outcomes it predicts accurately. To assess the correct model prediction, a comparison between the model predictions and the actual observations is necessary.

To further aid in the interpretation, the product of the standard deviations of the explanatory variables and model coefficients, reflecting the economic significance, is evaluated. It represents the change in the conditional expectation of the credit rating, in response to a one standard deviation change in the explanatory variable.

\section{Results and discussion}

We begin our analysis by presenting the univariate ordered probit model. These univariate tests provide an evaluation of the hypothesized relationships and the relative economic significance. The results are presented in table 2 . A positive coefficient indicates a higher credit rating (remember that the value 5 is assigned to the best rating category, for firms rated Aaa/Aa1/Aa2/Aa3). The debt coverage variable 'FFO/TD-aver', the variables reflecting the business profile, the variable reflecting the financial policy 'TD/CE-aver' and the variable reflecting the firm's liquidity 'QUI Rat-aver' are not significant. All the other coefficients are statistically significant.

The parameters $\alpha 1, \alpha 2, \alpha 3$ and $\alpha 4$ partition the standard normal distribution into five regions, one for each credit rating class. Consider, for example, their interpretation in relation to 'CUR Rataver'. According to the univariate model results, each company for which the product of the $\beta$ coefficient and the measured 'CUR Rat-aver' is greater than 1, 9082 is likely rated in Aaa-Aa1-Aa2Aa3 class. This corresponds to a 'CUR Rat-aver' of 16,3793; so firms with 'CUR Rat-aver' of 16,5 or more tend to have one of the best ratings that are Aaa, Aa1, Aa2 and Aa3. Similarly, a firm for which the product of the $\beta$ coefficient and the measured 'CUR Rat-aver' is between 1,9082 and 0,6600 is likely rated in the A1A2-A3 class. Thus, companies with an average of the overall liquidity ratio varying between 5,6652 and 16,3793 tend to have credit rating at the A1-A2-A3 class. Finally, firms rated in the Baa1-Baa2-Baa3 class are likely to have an average overall liquidity ratio varying between $(-4,884)$ and 5,6652 ; firms rated in the Ba1-Ba2-Ba3 class are likely to have an average overall liquidity ratio varying between $(-12,854)$ and $(-4,884)$; and firms whose the average overall liquidity ratio is less than $(-12,854)$ tend to receive one of the ratings of the first class $\mathrm{B} 1, \mathrm{~B} 2$ or $\mathrm{B} 3$.
However, the average overall liquidity ratio does not contain negative values in our sample: it varies between 0,2690 and 7, 1683 (see table 1). This allows us to predict that firms in the sample are all rated on the third (Baa1-Baa2-Baa3) or the fourth (A1-A2-A3) classes. Therefore, the univariate ordered probit model does not predict that any firms are in the Aaa-Aa1-Aa2-Aa3, Ba1-Ba2-Ba3 and B1-B2-B3 classes, based solely on the overall liquidity ratio. This may justified by the fact that the majority of firms in the sample are rated on the Baa1-Baa2-Baa3 and A1-A2-A3 classes (see figure 1).

Economic significance can be analyzed with reference to the final column in table 2 . The final column indicates how much the latent continuous variable $\mathrm{Y}^{*}$ it would move if the independent variables were one standard deviation greater. This will be interpreted with reference to the parameters $\alpha 1, \alpha 2, \alpha 3$ and $\alpha 4$. For example, the median of the current ratio is equal to 1,4759 . At this median value, $X^{\prime}$ it $\beta$ is equal to $0.1719(0.1165 \times 1.4759)$, which is between $\alpha 2$ and $\alpha 3$. This implies that the model would assign this median firm to the Baa1-Baa2-Baa3 class. An increase in the current ratio of one standard deviation would increase the estimate of $\mathrm{X}$ 'it $\beta$ by 0,1041 to 0,276 , which still belongs to the same interval $[\alpha 2, \alpha 3]$. Thus, this increase does not change the class of ratings that the firm belongs to. This indicates that the current ratio is economically insignificant.

To conclude, the effect of individual variables on the long term credit rating is minor and economically insignificant: the credit rating is a combination of several factors.

For this reason, we run another model that includes all variables simultaneously. First, we present the correlation between these variables in table 2 . The thirteen independent variables, except the interest coverage variable and the two variables reflecting the business profile, can be grouped into five pairs that address debt coverage, size, profitability, liquidity and financial policy. Table 2 shows large and significant correlations between the variables of each pair. In order to minimize the problems associated with multicollinearity, we estimate a model with only one variable of each pair. We are guided by the correlations with other variables, in our choice of variables.

Thus, our final model includes eight independent variables namely 'EBITDA/INT-aver', 'Bus-Seg-aver', 'Geo-Seg-aver', 'Rev-aver', 'FCF/TD-aver', 'ROA-aver', 'CUR-Rat-aver' and 'TD/CE-aver'. The results of the final ordered probit model are presented in table 4.

Table 4 suggests that all the independent variables, except for the two variables reflecting the company profile 'Bus-Seg-aver' and 'Geo-Seg-aver' and the variable reflecting profitability 'ROAaver', have a significant impact on credit ratings. Unlike Moody publications', the business profile is not determinant of the issuer long term credit rating. Similarly, the firm's profitability seems also not relevant.

For significant variables, all are in the predicted direction except for the debt coverage variable 'FCF/TD-aver', which admits a negative coefficient. The result can be explained by the fact that this variable is highly correlated with the interest coverage variable. 
Table 2: Univariate Ordered Probit Model Estimates of Independent Variables

\begin{tabular}{|c|c|c|c|c|c|c|}
\hline Variables & $\alpha 1$ & $\alpha 2$ & $\alpha 3$ & $\alpha 4$ & $\beta$ (Stan.Err) & $\beta \times$ Stan Devi \\
\hline Bus-Seg-Aver & $-1,5980$ & $-0,6772$ & 0,5533 & 1,7475 & $0,0318(0,0215)$ & 0,0528 \\
\hline Geo-Seg-Aver & $-1,6797$ & $-0,7584$ & 0,4641 & 1,6513 & $0,0041(0,0165)$ & 0,0088 \\
\hline Rev-Aver & $-1,6027$ & $-0,6797$ & 0,5692 & 1,7740 & $0,000007(0,000001) \mathrm{a}$ & 0,1311 \\
\hline EBITDA-Aver & $-1,6113$ & $-0,6979$ & 0,5549 & 1,7428 & $0,00004(0,00001) a$ & 0,1121 \\
\hline FFO/TD-Aver & $-1,8189$ & $-0,8342$ & 0,3735 & 1,5489 & $-0,0116(0,0315)$ & $-0,0156$ \\
\hline \multicolumn{7}{|l|}{ FCF/TD-Aver } \\
\hline D1 & -18105 & -08530 & & & & $-0,1627$ \\
\hline D2 & & $\begin{array}{l}-0,8550 \\
-07516\end{array}$ & $\begin{array}{l}0,4029 \\
04875\end{array}$ & $\begin{array}{l}1,0058 \\
1,6791\end{array}$ & $\begin{array}{l}-0,538(0,1246) a \\
-00882(01170)\end{array}$ & 0,02794 \\
\hline D3 & $-1,6966$ & $-0, / 516$ & $0,48 / 5$ & 1,6/91 & $-0,0882(0,11 / 0)$ & 0,0152 \\
\hline D4 & $-1,7296$ & $-0, / 85 \%$ & $\begin{array}{l}0,4526 \\
0,4667\end{array}$ & $\begin{array}{l}1,6453 \\
16579\end{array}$ & $\begin{array}{l}-0,0314(0,0764) \\
0.067\end{array}$ & 0,0387 \\
\hline \multicolumn{7}{|l|}{ EBITDA/INT-Aver } \\
\hline $\mathrm{K} 1$ & $-0,9073$ & 0,0078 & 1,2181 & 2,4479 & $0,1682(0,0413) a$ & 0,1543 \\
\hline $\mathrm{K} 2$ & $-1,4790$ & $-0,5687$ & 0,6360 & 1,8640 & $0,0610(0,0179) \mathrm{a}$ & 0,1303 \\
\hline K3 & $-1,6193$ & $-0,7141$ & 0,4807 & 1,7024 & $0,0135(0,0087) \mathrm{c}$ & 0,0588 \\
\hline K4 & $-1,6995$ & $-0,7919$ & 0,4033 & 1,6265 & $-0,0040(0,0020)$ & $-0,0719$ \\
\hline ROA-Aver & $-1,6286$ & $-0,7009$ & 0,5377 & 1,7332 & $0,0107(0,0053) b$ & 0,0709 \\
\hline QUI Rat-Aver & $-1,6444$ & $-0,7125$ & 0,5057 & 1,7467 & $0,0584(0,0518)$ & 0,0407 \\
\hline CUR Rat-Aver & $-1,4976$ & $-0,5691$ & 0,6600 & 1,9082 & $0,1165(0,0398) a$ & 0,1041 \\
\hline TD/EBITDA-Aver & $-1,8969$ & $-1,0163$ & 0,2399 & 1,4628 & $-0,0853(0,0224) a$ & $-0,1433$ \\
\hline TD/CE-Aver & $-1,7281$ & $-0,7953$ & 0,4370 & 1,6337 & $-0,00009(0,0005)$ & $-0,0063$ \\
\hline
\end{tabular}

Note: a, b, c indicate statistical significance at the $1 \%, 5 \%$ and $10 \%$ levels respectively.

Table 3: Correlation Matrix of Transformed and Business Profile Variables

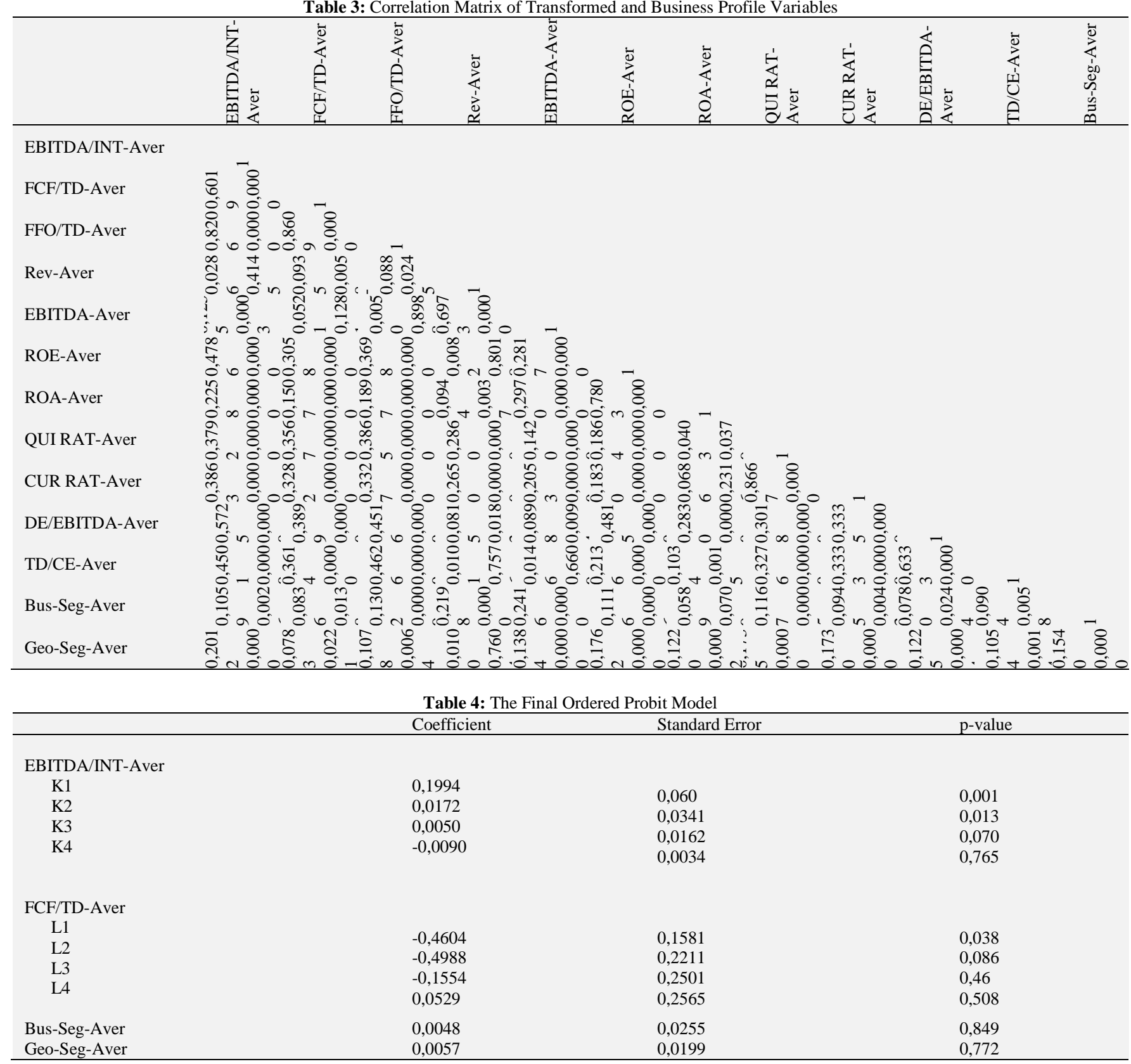




\begin{tabular}{lll}
\hline Rev-Aver & 0,00011 & 0,000024 \\
ROA-Aver & 0,0131 & 0,0108 \\
Cur-Rat-Aver & 0,293 & 0,0662 \\
TD/CE-Aver & $-0,0010$ & 0,0007 \\
Where : & \\
K1, K2, K3 et K4 denote the coefficients associated with the increments of the 'EBITDA/INT-Aver' respectively in the ranges [0, 5), [5, 10), [10, 20) and \\
[20, 100). \\
L1, L2, L3 et L4 denote the coefficients associated with the increments of the 'FCF/TD-Aver' respectively in the ranges [-1, 0), [0, 1), [1, 3) and [3, 5). \\
\hline
\end{tabular}

As we have presented above, different coefficients are associated with different increments of the debt coverage variable 'FCF/TDaver'. As expected, the results show that the coefficients associated with increments of this variable between $[-1,0)$ and $[0,1)$ are significant, while in excess of one, this ratio loses any significance in determining the issuer long term credit rating. This seems logical that debt coverage ratios greater than one does not reflect great capacity to cover debts. Instead, these ratios are the result of large numerators associated with small denominators due to special circumstances that do not reflect the company real situation.

Similarly, results support the findings of Blume et al. (1998) and Amato \& Furfine (2004) for the interest coverage variable. The coefficient associated with increments of 'EBITDA/INT-aver' from 0 to five is large, positive and significant, while the coefficients associated with increments from five to ten and from ten to twenty are also positive and significant but weaker, and beyond twenty, it becomes insignificant. Thus, higher interest coverage ratios are associated with higher credit ratings.

The variable reflecting firms' size 'Rev-aver' is significantly and positively associated with issuer long term credit rating. Thus, large firms enjoy higher credit rating quality.

The current ratio is also significantly and positively associated with long term credit rating. Firms with more liquid assets receive higher credit ratings.

Finally, the firms' financial policy, measured by 'TD/CE-aver' has a significant but negative effect on determining long term credit rating. This result seems logical and consistent with the theory: increasing business debts' increases the risk of non-repayment and therefore reduces the credit rating attributed.

\section{Conclusion}

We examine the impact that various financial and business profile variables have on credit ratings issued for the S\&P 500 index firms by Moody. The results indicate that firms' financial policy, size, liquidity, interest coverage and debt coverage have the most pronounced effect on credit ratings.

Our ordered probit model indicates that different coefficients are associated to the increments of interest and debt coverage ratios. Our results support the findings of Blume et al. (1998) and Amato \& Furfine (2004) for the interest coverage ratio. However, this paper is the first that explores the increments associated to the debt coverage variables. We show that coefficients associated to increments of the free cash flow to total debts ratio between negative one and zero and between zero and one are significant, while in excess of one, this ratio loses any significance. Debt coverage ratios greater than one don't reflect greater capacity to cover debts. Our study has also showed that liquidity is a significant determinant of the issuer long term credit rating and not just the short term one. This result is not supported by previous studies neither by Moody's rating methodology.

To conclude, the issuer long term credit ratings determinants' reflect already the firm's capital structure. While the interest coverage ratio depends on the debt interests', the debt coverage ratio depends on the debt amounts and the financial policy reflects the proportion of debts and equities in the capital.

\section{References}

[1] Amato JD \& Furfine CH (2004), Are credit ratings procyclical?, Journal of Banking \& Finance 28, 2641-2677. http://dx.doi.org/10.1016/j.jbankfin.2004.06.005.

[2] Altman EI \& Katz S (1976), Statistical bond rating classification using financial and accounting data, In Schiff M \& Sorter G, Proceedings of the Conference on Topical Research in Accounting (New York University Press), New York, 205-239.

[3] Blume ME, Lim F \& Mackinlay C (1998), the declining credit quality of U.S. corporate debt: Myth or reality? The Journal of Finance 53, 1389-1413. http://dx.doi.org/10.1111/0022-1082.00057.

[4] Boot AWA, Milbourn TT \& Schmeits A (2006), Credit ratings as coordination mechanisms. The Review of Financial Studies 19-1, 81-118.

[5] Cantor R \& Packer F (1994), the credit rating industry. Federal Reserve Bank of New York Quarterly Review 19-2, 1-26.

[6] Ederington LH (1985), Classification models and bond ratings. The Financial Review 20, 237-262. http://dx.doi.org/10.1111/j.15406288.1985.tb00306.x.

[7] Gray S, Mirkovic a \& Ragunathan V (2006), the determinants of credit ratings: Australian evidence. Australian Journal of Management 31-2, 333-354 http://dx.doi.org/10.1177/031289620603100208.

[8] Guttler a \& Wahrenburg M (2007), the adjustment of credit ratings in advance of defaults. Journal of Banking and Finance 31, 751767. http://dx.doi.org/10.1016/j.jbankfin.2006.05.014

[9] Horrigan JO (1966), the determination of long-term credit standing with financial ratios, Journal of Accounting Research 4, 44-62. http://dx.doi.org/10.2307/2490168.

[10] Huang Z, Chen H, Hsu CJ, Chen WH \& Wu S (2004), Credit rating analysis with support vector machines and neural networks: a market comparative study. Decision Support Systems 37, 543-558. http://dx.doi.org/10.1016/S0167-9236(03)00086-1.

[11] Hwang RC, Chung H \& Chu CK (2010), Predicting issuer credit ratings using a semi parametric method. Journal of Empirical Finance 17 ,

120-137. http://dx.doi.org/10.1016/j.jempfin.2009.07.007.

[12] Kaplan RS \& Urwitz G (1979), Statistical models of bond rat-ings: a methodological inquiry. Journal of Business 52, 231-261. http://dx.doi.org/10.1086/296045.

[13] Kennedy D, Lakonishok J \& Shaw W H (1992), Accommodat-ing Outliers and Nonlinearity in Decision Models; Professional Adaptation. Journal of Accounting, Auditing and Finance 7, 161-194.

[14] Kim KJ \& Ahn H (2012), A corporate credit rating model using multi-class support vector machines with an ordinal pairwise partitioning approach. Computers and Operations Research 39, 18001811. http://dx.doi.org/10.1016/j.cor.2011.06.023.

[15] Lee YC (2007), Application of support vector machines to corporate credit rating prediction. Expert Systems with Applications 33, 67-74. http://dx.doi.org/10.1016/j.eswa.2006.04.018.

[16] Moody's Investors Service (2010), Rating methodology Global Manufacturing Industry.

[17] Moody's Special Comment (2006), Moody's Credit Rating Prediction Model.

[18] Moody's Special Comment (2004), A User's Guide to Moody's Default Predictor Model: An accounting Ratio Approach.

[19] Moody's (2002), Moody's Rating Methodology Handbook, Sovereign, Moody's Investor Service Inc.New York, 90-98.

[20] Nenide B, Pricer RW \& Camp SM (2010), The use of financial ratios for research: problems associated with and recommendations for using large databases

[21] [21] Partnoy F (2002), the paradox of credit ratings, The New York University Salomon Center Series on Financial Markets and Institutions, 9, 65-84. http://dx.doi.org/10.1007/978-1-4615-0999-8_4.

[22] Pettit J, Fitt C, Orlov S \& Kalsekar A (2004), The new world of credit ratings, UBS Investment Bank. 
[23] Pinches GE \& Mingo KA (1973), a multivariate analysis of industrial bond ratings. Journal of Finance, 28, 1-18. http://dx.doi.org/10.1111/j.1540-6261.1973.tb01341.x.

[24] Pogue TF \& Soldofsky RM (1969), what's in a bond rating? Journal of Financial and Quantitative Analysis, 4, 201-228. http://dx.doi.org/10.2307/2329840.

[25] Poon WPH (2003), Are unsolicited credit ratings biased downward? Journal of Banking and Finance, 27, 593-614. http://dx.doi.org/10.1016/S0378-4266(01)00253-9.

[26] Standard and Poor's (2001b), Corporate Ratings Criteria, McGrawHill, New York.

[27] Standard and Poor's (2003), Corporate Ratings Criteria, Stand-ard and Poor's Corporation, New York.

[28] Standard and Poor's (2008), Corporate Ratings Criteria.

[29] Standard \& Poor's (2011), Sovereign Government Rating Methodology and Assumptions, Standard \& Poor's Ratings Direct on the Global Credit Portal, New York.

[30] Tanthanongsakkun S \& Treepongkaruna S (2008), Explaining credit ratings of Australian companies- An application of the Merton model. Australian Journal of Management, 33-2, 261-276. http://dx.doi.org/10.1177/031289620803300203.

[31] West RR (1970), an alternative approach to predicting corpo-rate bond ratings. Journal of Accounting Research, 8, 118-125. http://dx.doi.org/10.2307/2674717.

[32] Wijayatunga P, Mase S \& Nakamura M (2006), Appraisal of companies with Bayesian networks, International Journal of Business, 1-3, 329-346. http://dx.doi.org/10.1504/ijbidm.2006.009138. 